\title{
The contribution of geographic information systems and remote sensing in determining priority areas for hydrogeological development, Darb el-Arbain area, Western Desert, Egypt
}

\author{
Hossam H. Elewa • Rafik G. Fathy • Atef A. Qaddah
}

\begin{abstract}
The Darb el-Arbain study area is in the southern Western Desert of Egypt and has been attracting increasing developmental interest in the last few decades, especially since agricultural development of the southern Baris area, where the groundwater resources of the Nubian Sandstone Aquifer System (NSAS) have been utilized for the cultivation of valuable lands. Due to the proven high potential of both groundwater and land resources, determining the priority areas for sustainable hydrogeological development becomes a necessity. A geographic information system, as a platform for geospatial modeling techniques, has been built, which depends on the recently collected data about the NSAS, in addition to the published databases. Certain criteria of practical value, like depth to groundwater, hydraulic conductivity, groundwater salinity, sodium adsorption ratio, and the safe yield of wells, were selected as decisive parameters for hydrogeological prioritization. The model pinpoints areas characterized by favorable hydrogeological conditions, which could be used for future development and implementation of an artificial storage and recovery (ASR) program. The designated priority areas for hydrogeological development occur at the southern, middle southern and some localized northern parts of the Darb el-Arbain area. The newly formed Tushka Lakes represent a suitable and excellent natural source of freshwater for implementing an ASR program.
\end{abstract}

Received: 21 April 2009 / Accepted: 3 February 2010

Published online: 9 March 2010

(C) Springer-Verlag 2010

H. H. Elewa (『)

National Authority for Remote Sensing \& Space Sciences (NARSS), 23 Jozef Brows Tito St., El Nozha El Gedida, 11769, P.O. Box 1564 (Alf-Maskan), Cairo, Egypt

e-mail: hossh2@yahoo.com

Tel.: +20105831735

Fax: +20226225800

R. G. Fathy

General Authority for Rehabilitation Project and Agricultural Development (GARPAD), 14 Tahran St., Dokki, Giza, Egypt

A. A. Qaddah

Egyptian Environmental Affairs Agency (EEAA),

Teraat El Mansuriyah St., El-Mansura, Egypt
Keywords Egypt $\cdot$ Remote sensing · Geographic information systems - Geospatial modeling .

Nubian sandstone aquifer system

\section{Introduction}

The study area is located in the southern part of the Western Desert of Egypt. It lies between latitudes $22^{\circ} 00^{\prime}$ $8.19^{\prime \prime}-25^{\circ} 00^{\prime} 27^{\prime \prime} \mathrm{N}$ and longitudes $29^{\circ} 13^{\prime} 22.33^{\prime \prime}-30^{\circ} 56^{\prime}$ 13" E (Fig. 1). As Egypt is essentially a desert land (about 94\%), great consideration is given to desert reclamation and to the utilizing the groundwater, which is the sole resource to be used for different purposes such as domestic use and irrigation. The Darb el-Arbain area has attracted considerable attention with respect to the exploration and exploitation of the Nubian Sandstone Aquifer System. The natural resources of this area cover the demands for the ongoing reclamation and housing projects, where the good soils and groundwater resources are important factors. In the last few decades, intensive drilling for groundwater has been performed; there are now about 90 wells (Fig. 2). Several rural villages have been established, which depend on the newly explored and exploited groundwater resources. Accordingly, migration of people from overpopulated areas in the Nile Valley and New Valley areas has taken place towards the newly initiated settlements in this far southern area of Egypt. The principal goal of this national project is to reclaim 12,000 feddans $(12,456$ acres) and to build 16 villages for farmers along a section of about $400 \mathrm{~km}$, from Baris town to the political borders between Egypt and Sudan in the south. The area concerned could be taken as an example of poverty alleviation through installment of new communities but it is dependent on the available water resources.

\section{Climatic conditions}

From the climatic point of view, the area is located in an arid region, where the maximum air temperature is $48.6^{\circ} \mathrm{C}$ in May and the minimum is $-2.1^{\circ} \mathrm{C}$ in February. The annual rainfall does not exceed $1.1 \mathrm{~mm}$; there is a maximum total monthly rainfall of $0.3 \mathrm{~mm}$ occurring in December to February. The annual evaporation is about 


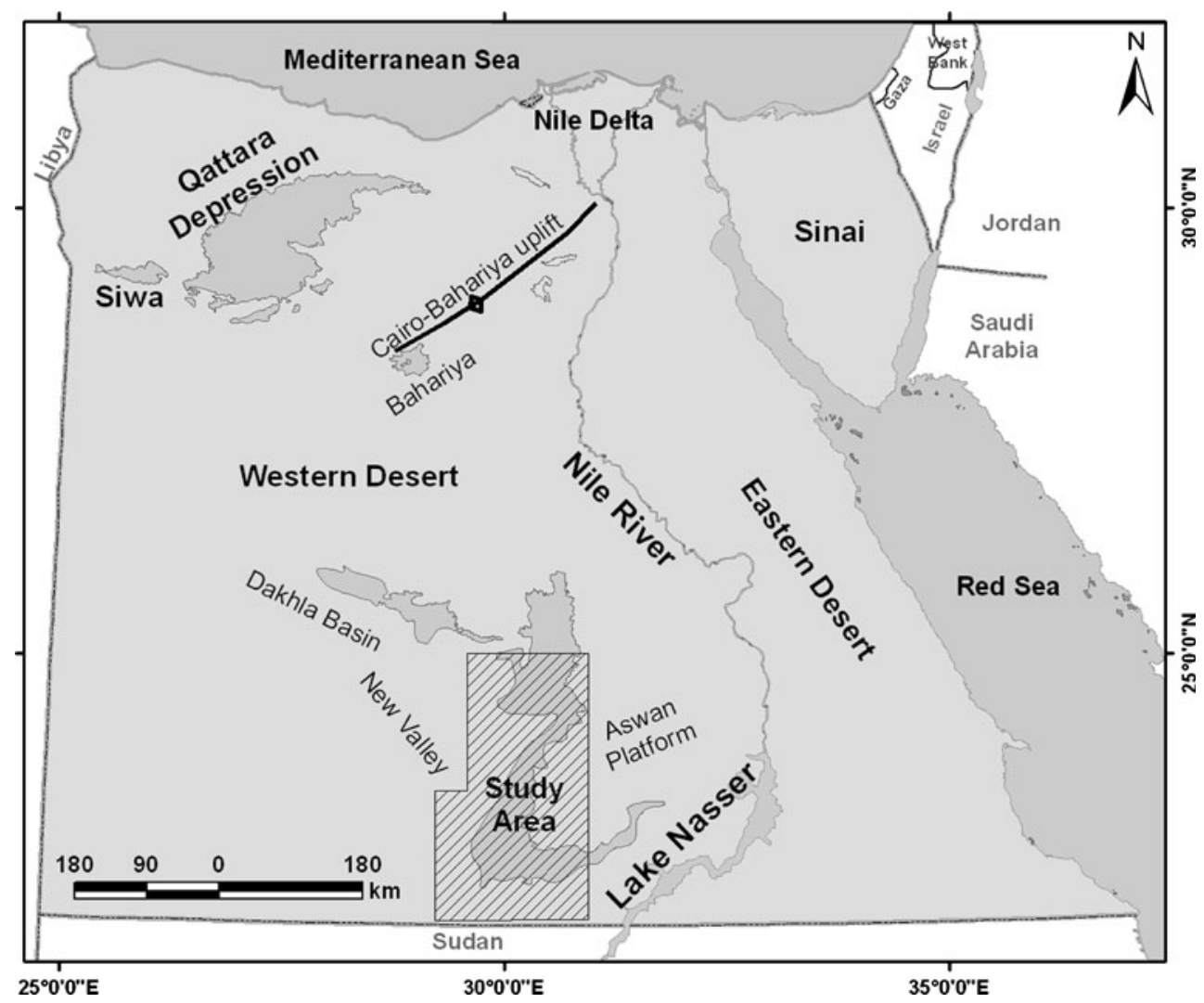

Fig. 1 Location map of the study area in Egypt

$17.2 \mathrm{~mm}$, with a maximum monthly evaporation rate of about $21.3 \mathrm{~mm}$ occurring in June (Korany et al. 2002).

\section{Geologic and geomorphic setting}

According to Issawi (1978), the Darb el-Arbain area is sub-divided into three geomorphic units. These units are the southern Nakhlai-Shab pediplain, the western Atmur peneplain, and the plateau surface. Generally, the area is dissected by faults. The geology of Darb el-Arbain area is covered mainly by Upper Cretaceous to lower Tertiary sediments which unconformably underlie the Quaternary deposits with exposures of basement igneous and metamorphic rocks belonging to Late Precambrian to Early Paleozoic age (CONOCO 1989; Fig. 3).

The subsurface succession at Darb el-Arbain was determined from the 90 drilled production wells (fully penetrating). Three distinctive subareas are delineated and, hence, chosen to locate three groundwater production fields (Fathy et al. 2002). These wells penetrate about 400 to $500 \mathrm{~m}$ thick sediments of shale (Dakhla Shale Formation; Upper Cretaceous age), shaly sandstone, sandstone and shale intercalations-Kiseiba and Taref Sandstones (Nubian Sandstones); Cretaceous age-and undifferentiated Paleozoic-Mesozoic sandstones (Fathy et al. 2001; Korany et al. 2002) (Fig. 4).

Structural elements (especially faults) play an important role in the hydrogeologic setting of the study area, where it is affected by a number of major faults that are arranged in NNW-SSE, NNE-SSW and W-E directions forming a step-like faulting system. The faulting pattern establishes horst and graben structures, which caused a great deal of facies and thickness changes (Fig. 4). The newly delineated subsurface faults were determined from the results of the full penetration drillings (which touch the basement). As the elevation is known for each drilled site, it was easy to determine the level of the top surface of the basement rocks above mean sea level. In all, 66 previously-unrecorded normal faults have been delineated; 19 normal faults in the northern area, 26 in the middle area, and 21 normal faults in the Bir El Shab (southern) area. Step-like faulting, graben and horst geological structures (Figs. 4 and 5) have also been delineated for the first time (Fathy 2003, 2004):

- N-S faults: 9

- E-W faults: 11

- NE-SW faults: 22

- NW-SE faults: 24

Accordingly, the NW-SE faults are the most frequent ones (Figs. 4 and 5). The most effective faults were traced clearly on the Landsat satellite ETM+ image and their hydrogeological significance was confirmed and assessed by the drilled wells data (Figs. 4 and 5).

The Nubian Sandstone is the main exploitable waterbearing formation. This vital aquifer is used for the agricultural and socio-economical development of the whole southern Western Desert of Egypt. This aquifer was formed by the local infiltration during the past wet 


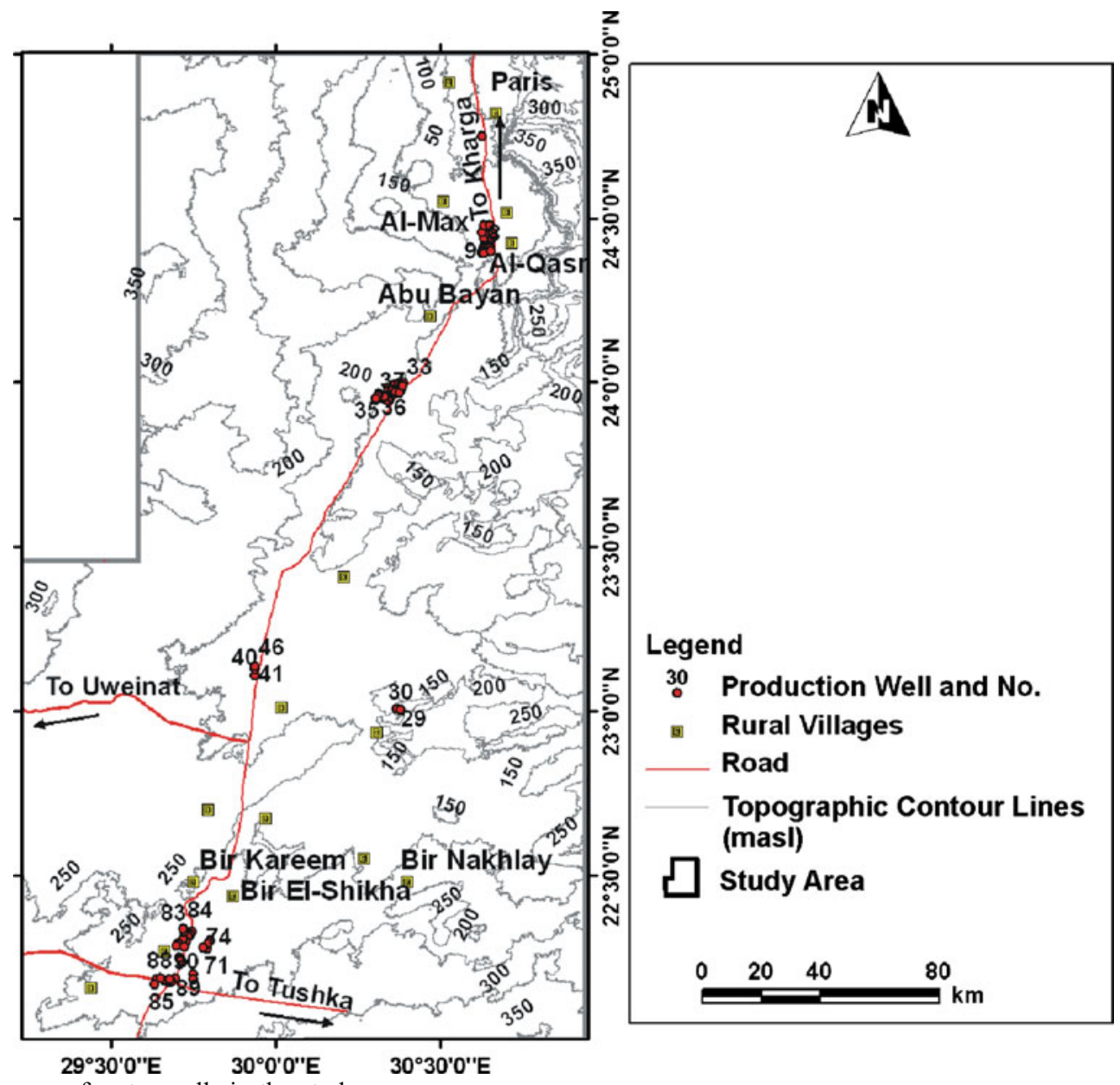

Fig. 2 Location map of water wells in the study area

periods (pluvial periods), which ended in the northeastern Sahara about 8,000 years ago, while it ended in the south about 4,000 years ago (Heinl and Thorweihe 1993).

Regionally speaking, the Nubian Sandstone Aquifer System is the Sahara's most important easterly groundwater province. It covers southeast Libya, Egypt, northeast Chad, and northern Sudan with a total area of about 2 million $\mathrm{km}^{2}$. The Nubian Sandstone Aquifer System is a closed hydrogeological system. In the Western Desert of Egypt, it is bounded from the east, south and south east by basement outcrops, while in the north, it is bounded by a fresh/saline water interface located in the vicinity of the Qattara Depression (Said 1962). In the study area, the Nubian Sandstone Aquifer System occurs within the Dakhla Basin, where the maximum thickness of sediments ranges between 3,500 and 4,000 $\mathrm{m}$ in the northern part of the Dakhla Basin (Klitzsch and Squyres 1990). Compared to this thickness range, the Aswan Platform, which is the eastern extension of the Dakhla Basin, contains small groundwater resources due to its small sediment thickness reaching a few hundred meters only. North of the Dakhla Basin lies the Northwestern Basin of Egypt, which occurs northwest of the Cairo-Bahariya Uplift and which separates it from the Dakhla Basin to the south of it, with sedimentary thickness of over $4,000 \mathrm{~m}$ (Klitzsch and
Squyres 1990). Only the southernmost strip of the Northwestern Basin, however, stretches south of the saline/ freshwater interface. Therefore, it is of marginal importance for the Nubian Sandstone Aquifer System (Heinl and Thorweihe 1993).

From the data derived from 90 drilled wells (Fathy et al. 2002) in the Darb el-Arbain area, it is concluded that the hydrogeological framework consists, from top to bottom, of Kiseiba Formation and Taref Formation (water bearing layers) (Figs. 3 and 4) in the middle and southern parts, whereas in the northern part, the water bearing layers are the Quseir Formation (which replaces Kiseiba Formation; they have the same age and thickness) and the Taref Formation. The lower part of the Quseir Formation (CONOCO Map 1987) is made up of alternating claystone, siltstone, sandstone and intraformational conglomerate from a marginal marine tidal-flat environment and is proved to be water bearing by evidence from drilling (Fathy et al. 2002).

\section{Kiseiba formation}

It is composed mainly of fine-to-medium sandstone with a thin layer of ferruginous sandstone and some intercalations with about $10 \%$ grey shale. The latter are considered 

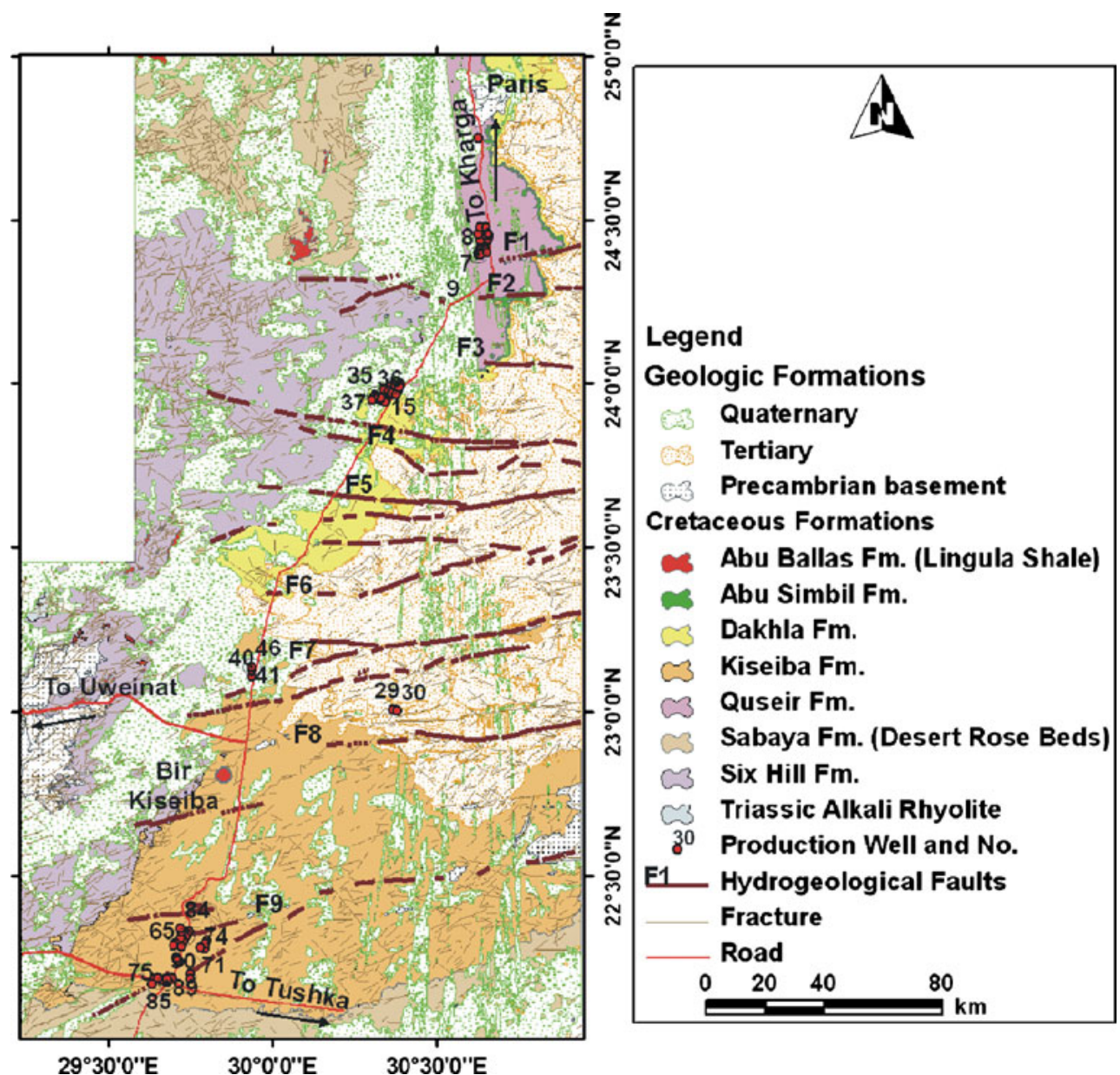

Fig. 3 Geological and structural map of the Darb el-Arbain area (based on CONOCO 1987, NG36SW-Luxor Sheet, and Landsat satellite ETM+ image mosaics taken in 2000)

as a confining (aquitard) layer and the Kiseiba Formation is proven to be a confined aquifer (Figs. 3 and 4). The Kiseiba Formation belongs to the Campanian-Maastrichtian age. It is capped by the Dakhla Formation of the Maastrichtian to Paleocene age in the middle part only. During the Campanian, the predominant continental history came to an end and shallow marine sediments were accumulated. Kiseiba Formation is described also as the Variegated Shale by Said $(1962,1990)$. During the Late Cretaceous, initial strike-slip movement along the present-day Red Sea axis occurred, which converted the Pan African E-W striking shear planes into normal faults under tensional conditions. Hence, horst and graben structures were formed in the study area (Said 1990; Fig. 4). In the subsurface, the thickness of this unit ranges from $100 \mathrm{~m}$ in the south to $70 \mathrm{~m}$ in the north. The variation in thickness of this unit is mainly attributed to the structural deformation in the study area (Fig. 4).

\section{Taref formation}

Taref Sandstone is the main aquifer in the Darb el-Arbain area, and it represents the main source of exploitable groundwater. This formation represents the oldest sedi- mentary rock unit in the south El Shab area of Darb elArbain, where it underlies the Kiseiba claystone unit and overlies, unconformably, the crystalline basement rocks. It is composed mainly of fine-to-coarse-grained sandstone, tabular cross-bedded with conglomeratic sandstones, and intercalations of marine deposits. The Taref Formation represents the fluviatile environment of Turonian to Santonian age (CONOCO 1987; Fig. 3). The thickness of this aquifer ranges from 56 to $202 \mathrm{~m}$, while the average thickness attains about $89 \mathrm{~m}$ (Fathy et al. 2002). Generally, the Taref thickness decreases southwards. The thickness variation is essentially attributed to the structural deformation of the study area, where the minimum thickness is encountered at the up-thrown side of the faulting system, as the erosional processes minimized the formation thickness (i.e. wells 39 and 65). On the other hand, the maximum thickness is encountered at the downthrown side of the faulting system (i.e. wells 9, 35, 59; Fig. 4).

The sand content of this aquifer varies from 66 to $81 \%$, while the average sand percentage is about $74 \%$ (Ghoubashi 2004). It should be noted that only a Paleozoic-Mesozoic sandstone layer exists in both the northern and the middle parts of the area of study which directly overlies the basement rocks. 


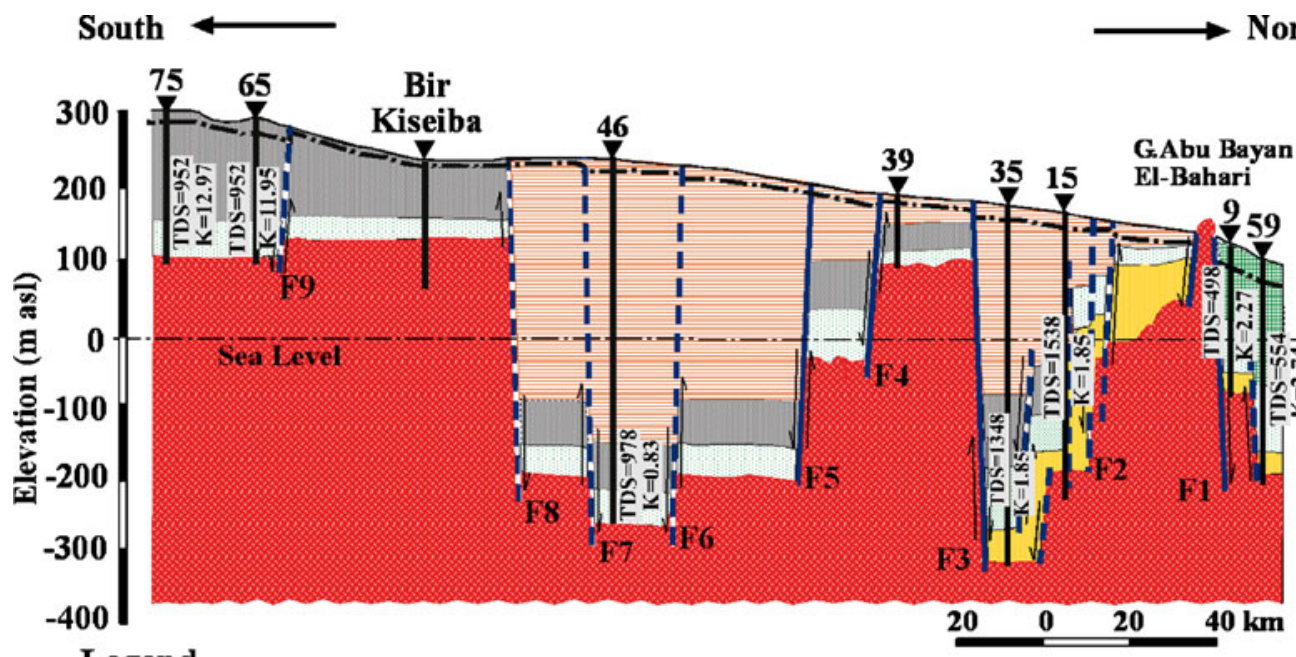

Legend

\begin{tabular}{|l|l|}
\hline Kiseiba Formation (U. Cretaceous) & Dakhla Formation (U.Cretaceous) \\
\hline Taref Formation (U.Cretaceous) & Quseir Formation (U.Cretaceous) \\
$\begin{array}{l}\text { Undifferentiated Paleozoic-Mesozoic } \\
\text { Sandstones }\end{array}$ & $\begin{array}{l}\text { Fault plane, dashed where inferred, } \\
\text { with throw direction }\end{array}$ \\
$\begin{array}{ll}78 \text { Crystalline basement rocks (Precambrian) } \\
\text { Production well \& No. }\end{array}$ & $\begin{array}{l}\text { K= Hydraulic Conductivity of } \\
\text { water-bearing horizon (m/day) }\end{array}$ \\
\hline TDS= Total Dissolved Solids (ppm) & Equipotentiometric surface (masl)
\end{tabular}

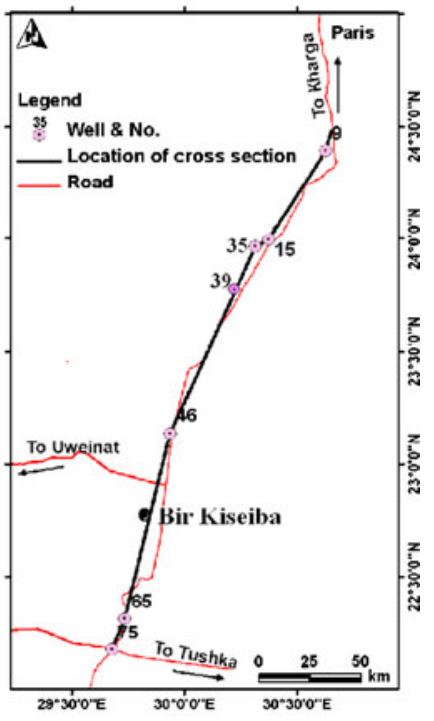

Key map for cross section water-bearing horizon ( $\mathrm{m} / \mathrm{day}$ )

Fig. 4 N-S subsurface hydrogeological cross section of Nubian Sandstone succession in the Darb el-Arbain area (modified after Fathy et al. 2002)

\section{Materials and methodology}

The methodology adopted in the present work is presented schematically in Fig. 6, and described briefly as:

- Landsat satellite ETM+ image (taken in 2000) processing and interpretation for extracting linear features (hydrogeological fractures and/or faults) and planning for future possible groundwater artificial recharging and aquifer development planning

- On-screen digitizing with the aid of ArcGIS 9.x software (ESRI 2007), where various hardcopy maps were converted into digital formats

- Compiling data from well records, pumping tests and hydrochemical analyses. These form an adequate infrastructure for executing a geographic information system (GIS)-based binary geospatial model for determining the hydrogeological priority areas for development (Fig. 6). This model represents a technique used to create an integrated analysis of different inputs (Malczewski 1999).

\section{Building a GIS geospatial model}

Geographic information system (GIS) tools can be used to build better models faster and more efficiently than traditional modeling techniques. Models built using GIS tools produce more refined modeling results, which can be exported back for data update and/or accessibility by other users such as planners and developers. These refined modeling results ultimately lead to better decision-making and more appropriate costs for capital improvements. It is generally agreed that the integration of GIS with hydrogeological data has enabled scientists to go beyond data management and thematic mapping to perform sophisticated analysis and simulation for both scientific research and policy analysis.

The GIS geospatial model performed is based on the hydrogeological and hydrogeochemical parameters that will be discussed. The GIS system is composed of a multilayer system of the fruitful interpretative maps, which would convey the potential for water use maximization associated with the proposed sustainable development activities. The complexity and types of questions that could be answered by GIS are: locations, conditions, trends, patterns, and priority areas for hydrogeological development.

The Spatial Analyst extension in ArcGIS 9.x software provides a broad range of powerful spatial data modeling and analysis tools seamlessly integrated into the ArcView environment. This extension allows one to create, visualize, and query cell-based raster data and combine vector and raster data for display and analysis. The hydrogeological data variables in the study area are spatial objects and tend to have indeterminate boundaries (see Burrough and Frank 1995 and the references therein). These objects are called fuzzy objects, and are characterized by indeterminate boundaries, changing in space over time, and are inseparably intertwining the representation of space and time as they relate to our (experiential) 


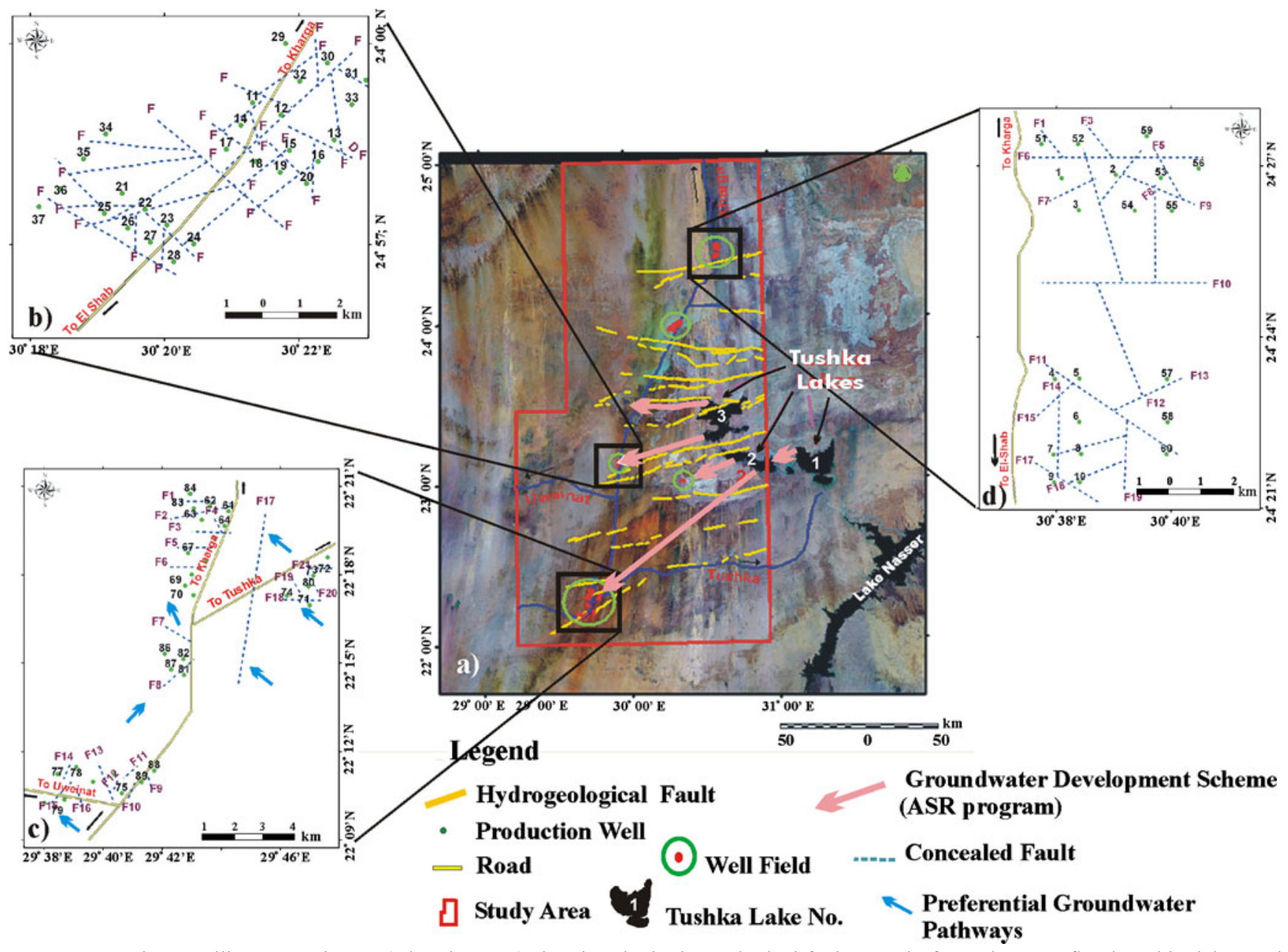

Fig. 5 a Landsat satellite ETM+ image (taken in 2000) showing the hydrogeological faults, newly formed excess-flood Tushka lakes and drilled-well fields; b-d detailed subsurface structural setting from well logging data

world. In the present work, fuzzy objects can be defined as fuzzy subsets of a referential set in a domain under consideration (i.e. depth to groundwater, groundwater salinity, hydraulic conductivity, sodium adsorption ratio, and well safe yield), which are obtained by assigning to points (pixels) membership values belonging to $[0,1]$. In order to enable GIS to respond to these types of queries, two fundamental problems have to be solved. First, a schema for representing a fuzzy region in GIS has to be developed (i.e. setting optimum values for determining parameters, which were determined according to the local prevailing hydro-economical conditions characterizing the study area); and second, a mechanism for approximately analyzing the binary topological relations between fuzzy regions has to be developed within the ArcGIS software platform.

However, the mechanism of binary modeling (patterns) depends on presence/absence of some specific economical or practical conditions. This makes it suitable for determining the priority areas for hydrogeological development and, therefore, the areas suitable for performing an artificial storage recovery (ASR) program. Accordingly, this model uses logical expressions to select map features from a composite map or multiple grids. Output of a binary model is in binary format:

- 1-True for map features that satisfy the logical assumption

- 0-False for map features that do not satisfy the logical assumption

- Taking the mean value of each model parameter as a determining number for specifying the hydrogeological priority areas (Tables 1 and 2)

The transmissivity $(T)$, hydraulic conductivity $(K)$, storage coefficient $(S)$ and well safe yield $(Q)$ were determined by higher quality pumping tests performed by GARPAD (unpublished report, 1998/2000) by using the Theis (1935) type curve or Cooper and Jacob (1946) straight line method (for example; Kruseman et al. 1990). The authors reviewed the analyses for model accuracy.

\section{Results and discussion}

The Nubian Sandstone Aquifer System is confined in all places in the southern part (South El-Shab area), the 


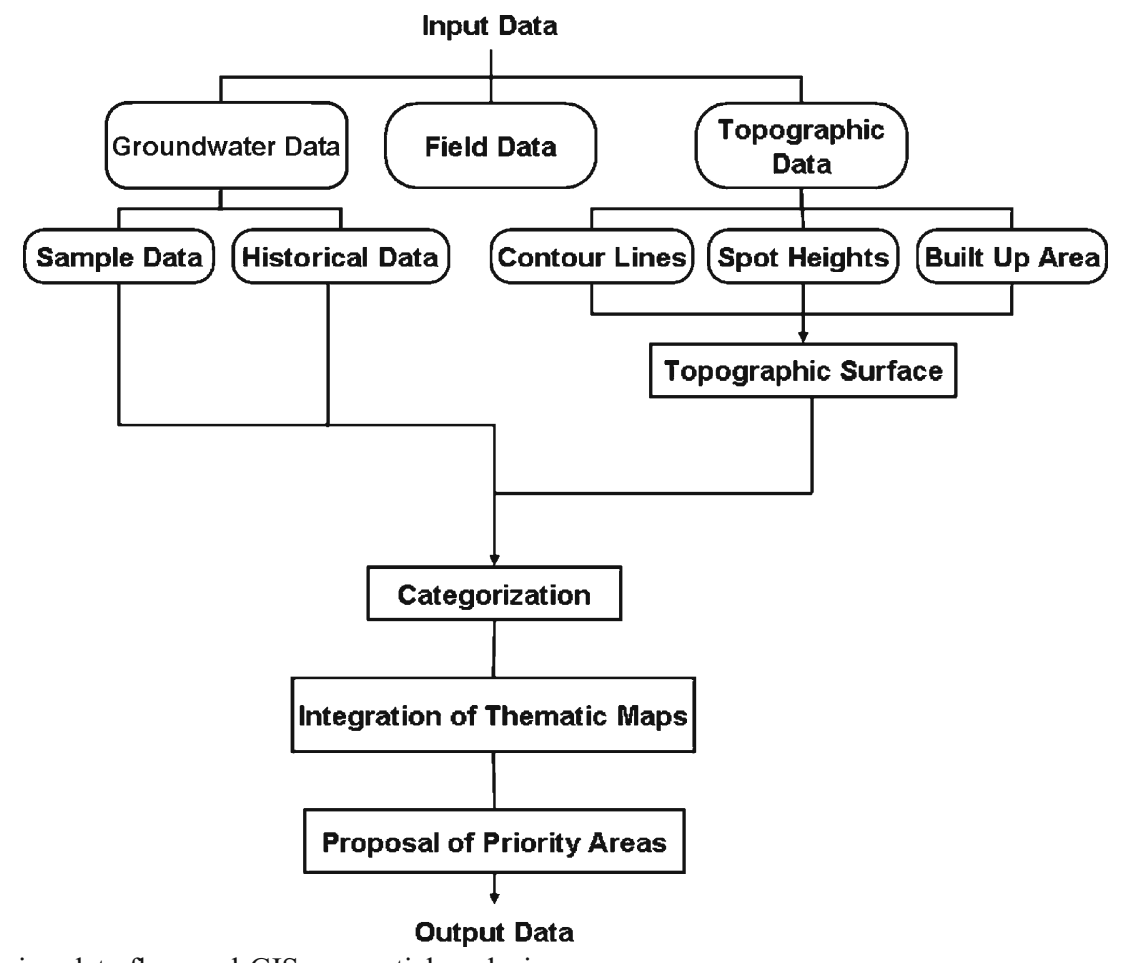

Fig. 6 Flow chart showing data flow and GIS geospatial analysis

middle part, and in the northern part. More than 90 wells are drilled in the Darb el-Arbain area (Fig. 2) with a total discharge of not less than 48.6 million $\mathrm{m}^{3} /$ year (about $180 \mathrm{~m}^{3} / \mathrm{h}$ discharge, with $10 \mathrm{~h}$ of daily working and 300 days/yea). On the other hand, other sources of official published information (Fathy et al. 2001, 2002; Fathy $2003,2004)$ give higher extraction values than those just mentioned for a slightly earlier period (1992), which may give rise to confusion and also highlight the critical need for reliable data in order to determine the real abstraction rates, and to assess, adapt, predict, and also manage these rates for best development plans. Groundwater modeling techniques may be followed to predict the future scenarios of water levels, expected drawdown and extraction values.

\section{Aquifer thickness variation}

Aquifer thickness is strictly controlled by the structural setting of the study area. The sedimentary succession varies from north to south due to the intensive faulting, which caused horst and graben structural patterns to prevail. Water bearing formations (Taref and Kiseiba Formation) exhibit thickness variation due to this faulting system (Figs. 4 and 5). The aquifer thickness of Taref and Kiseiba Formation attains maximum values at the central parts of the area, where it varies from $143 \mathrm{~m}$ (well 30) to $202 \mathrm{~m}$ (well 34) in the middle part and from $107 \mathrm{~m}$ (well 62) to $192 \mathrm{~m}$ (well 65) in the southern part (Bir El-Shab area) (Fathy 2003). The thickness of Kiseiba Formation decreases considerably towards the northern parts till the appearance of the Quseir Formation (equivalent to Kiseiba Formation) (wells 9 and 59). In the northern part (southern Baris area), the aquifer thickness ranges from $211 \mathrm{~m}$ (well 58) to 343 m (well 59) (Fig. 4; Fathy 2003, 2004).

\section{Equipotentiometric surfaces}

However, the same structural setting is responsible for the local hydrogeological setting in Darb el-Arbain area. The confined conditions of water bearing layers and the equipotentiometric variation are also structurally controlled. At the central part of the area, a big thickness of the impervious Dakhla Shale Formation is encountered. This formation favors the confined or semi confined conditions of the aquifer system, as the equipotentiometric levels are near ground surface or a little above it. On the other hand, semi confined conditions prevail due south and north of the middle part (Fig. 4). Nine effective hydrogeological faults were detected by the interpretation of the Landsat ETM+ satellite imagery and were subsequently verified in the field and by the data of drilled groundwater wells (Fig. 5). Some of these faults caused a specific drop or rise in the potentiometric surface, as the case in F9, which caused a drop in potentiometric surface towards its southern downthrown side by about $10-15 \mathrm{~m}$, and cancelling the effect of topography in normal conditions. Faults F1, F2, F4 and F7 establish similar modification in potentiometric levels, where depressed levels are encountered at their downthrown sides (Fig. 4). However, a computerized equipotentiometric and flownet map reflects a variation in potentiometric surfaces from 220 masl in the S-SW to 40 masl in the NE (Fig. 7). The map clearly emphasizes the role of subsurface structures in the segmentation of the aquifer into separated blocks, where there is a big variation between maximum and minimum equipotentiometric levels (40-220 m within $290 \mathrm{~km}$ ). The study area is composed of three separate hydrogeological provinces (Fathy et al. 2002). The groundwater movement is generally from south to north, 
Table 1 Parameters used for determining hydrogeological priority areas for development

\begin{tabular}{|c|c|c|c|c|c|c|c|c|c|}
\hline Well No. & $\begin{array}{l}\text { TDS } \\
\text { (ppm) }\end{array}$ & SAR & $\begin{array}{l}\text { Well safe } \\
\text { yield }(Q) \\
\left(\mathrm{m}^{3} / \mathrm{h}\right)\end{array}$ & $\begin{array}{l}\text { Tested useful } \\
\text { thickness } \\
\text { (Screened } \\
\text { portion) (m) }\end{array}$ & $\begin{array}{l}\text { Depth to } \\
\text { water } \\
\text { (mbgl) }\end{array}$ & $\begin{array}{l}\text { Transmissivity } \\
\text { (T) from } \\
\text { pumping tests } \\
\left(\mathrm{m}^{2} / \text { day }\right)\end{array}$ & $\begin{array}{l}\text { Hydraulic } \\
\text { conductivity } \\
\text { (K) from } \\
\text { pumping tests } \\
\text { (m /day) }\end{array}$ & $\begin{array}{l}\text { Piezometric } \\
\text { surface } \\
\text { (masl) }\end{array}$ & $\begin{array}{l}\text { Storage } \\
\text { coefficient } \\
\text { (S) }\end{array}$ \\
\hline 1 & 456.00 & 1.65 & 150.00 & 170.55 & 18.43 & 538.50 & 2.36 & 61.57 & 0.000030 \\
\hline 2 & 450.00 & 1.59 & 150.00 & 152.36 & 19.76 & 490.50 & 1.78 & 60.25 & 0.000115 \\
\hline A3 & 660.00 & 2.60 & 145.00 & 170.38 & 25.65 & 623.00 & 2.71 & 57.35 & 0.000207 \\
\hline 4 & 512.00 & 2.15 & 150.00 & 124.84 & 31.32 & 404.20 & 2.29 & 75.65 & 0.000195 \\
\hline 5 & 884.00 & 3.77 & 150.00 & 137.30 & 29.18 & 362.40 & 1.85 & 74.82 & 0.000250 \\
\hline 6 & 732.00 & 3.13 & 150.00 & 126.81 & 32.49 & 277.20 & 1.52 & 72.51 & 0.000541 \\
\hline 7 & 655.00 & 3.48 & 150.00 & 121.16 & 31.00 & 431.20 & 2.41 & 71.00 & 0.000207 \\
\hline 8 & 752.00 & 3.04 & 72.00 & 126.95 & 30.32 & 459.20 & 2.65 & 59.68 & 0.000134 \\
\hline 9 & 498.00 & 2.91 & 150.00 & 121.27 & 35.54 & 377.10 & 2.27 & 64.46 & 0.000170 \\
\hline 10 & 682.00 & 3.53 & 61.00 & 122.74 & 33.31 & 355.00 & 2.26 & 65.69 & 0.000120 \\
\hline 11 & 1160.00 & 5.95 & 190.00 & 201.13 & 20.92 & 375.00 & 2.07 & 124.98 & 0.000265 \\
\hline 12 & 1100.00 & 6.03 & 190.00 & 232.16 & 16.50 & 360.00 & 1.71 & 125.70 & 0.000141 \\
\hline 13 & 1426.00 & 6.69 & 190.00 & 194.31 & 9.25 & 250.00 & 1.45 & 124.55 & 0.000170 \\
\hline 14 & 1230.00 & 6.25 & 190.00 & 201.28 & 18.40 & 340.00 & 1.90 & 126.80 & 0.000105 \\
\hline 15 & 1538.00 & 7.02 & 190.00 & 205.70 & 12.20 & 320.00 & 1.85 & 123.18 & 0.000108 \\
\hline 16 & 1410.00 & 7.30 & 190.00 & 188.46 & 7.90 & 275.00 & 1.03 & 123.43 & 0.000177 \\
\hline 17 & 1476.00 & 6.23 & 190.00 & 266.32 & 17.80 & 270.00 & 1.22 & 126.30 & 0.000111 \\
\hline 18 & 1460.00 & 7.43 & 190.00 & 240.91 & 15.15 & 226.00 & 1.85 & 125.51 & 0.000112 \\
\hline 19 & 1548.00 & 7.26 & 190.00 & 245.70 & 11.33 & 360.00 & 1.70 & 123.67 & 0.000078 \\
\hline 20 & 1554.00 & 8.30 & 190.00 & 256.98 & 8.09 & 305.00 & 1.51 & 122.41 & 0.000113 \\
\hline 21 & 1640.00 & 7.13 & 190.00 & 245.76 & 22.50 & 345.00 & 1.65 & 125.66 & 0.000139 \\
\hline 22 & 1660.00 & 6.75 & 190.00 & 250.33 & 19.30 & 240.00 & 1.17 & 125.16 & 0.000115 \\
\hline 23 & 1492.00 & 6.32 & 190.00 & 283.29 & 15.64 & 326.00 & 1.61 & 125.75 & 0.000111 \\
\hline 24 & 1780.00 & 7.42 & 190.00 & 222.80 & 13.25 & 280.00 & 1.56 & 122.95 & 0.000129 \\
\hline 25 & 1542.00 & 7.05 & 190.00 & 251.24 & 22.10 & 379.20 & 1.80 & 127.56 & 0.000089 \\
\hline 26 & 1600.00 & 6.35 & 190.00 & 251.27 & 21.10 & 330.00 & 1.53 & 124.50 & 0.000109 \\
\hline 27 & 1600.00 & 7.63 & 190.00 & 245.56 & 16.00 & 325.20 & 1.60 & 128.80 & 0.000145 \\
\hline 28 & 1870.00 & 8.31 & 190.00 & 257.03 & 12.08 & 381.60 & 1.91 & 126.52 & 0.000100 \\
\hline 29 & 916.00 & 5.68 & 190.00 & 222.78 & 25.85 & 255.40 & 1.37 & 124.35 & 0.000089 \\
\hline 30 & 1124.00 & 6.95 & 190.00 & 208.76 & 15.90 & 308.15 & 1.77 & 125.79 & 0.000106 \\
\hline 31 & 1212.00 & 7.07 & 190.00 & 228.50 & 11.20 & 278.70 & 1.41 & 127.43 & 0.000109 \\
\hline 32 & 1348.00 & 6.27 & 190.00 & 211.32 & 17.90 & 379.40 & 2.12 & 124.76 & 0.000107 \\
\hline 33 & 1320.00 & 7.08 & 190.00 & 216.98 & 15.64 & 302.00 & 1.69 & 115.46 & 0.000103 \\
\hline 34 & 1352.00 & 6.22 & 190.00 & 243.75 & 27.00 & 320.20 & 1.50 & 125.42 & 0.000171 \\
\hline 35 & 1348.00 & 5.81 & 190.00 & 239.85 & 17.80 & 393.80 & 1.89 & 139.80 & 0.000179 \\
\hline 36 & 1480.00 & 6.55 & 190.00 & 217.25 & 24.43 & 413.50 & 2.38 & 134.77 & 0.000195 \\
\hline 37 & 1660.00 & 6.50 & 190.00 & 217.01 & 29.43 & 547.00 & 2.98 & 131.17 & 0.000191 \\
\hline 40 & 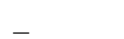 & - & 61.00 & 256.98 & 16.35 & 10.65 & 0.05 & 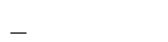 & 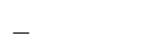 \\
\hline 41 & - & - & 61.00 & 291.25 & 9.20 & 14.81 & 0.14 & - & - \\
\hline 46 & $\overline{9} 78.00$ & $\overline{1} 7.68$ & 150.00 & 120.10 & 2.30 & 81.11 & 0.83 & $\overline{1} 90.00$ & - \\
\hline 51 & 715 & 3.17 & 65 & 200.04 & 32.00 & 525.00 & 2.67 & 54.00 & $\overline{0} .000185$ \\
\hline 52 & 550 & 3.35 & 72 & 165.76 & 28.00 & 722.10 & 2.71 & 52.00 & 0.000160 \\
\hline 53 & 530 & 2.50 & 145 & 177.10 & 28.50 & 497.50 & 1.85 & 50.50 & 0.000225 \\
\hline 54 & 820 & 3.69 & 65 & 154.20 & 22.00 & 301.50 & 1.28 & 61.00 & 0.000225 \\
\hline 55 & 482 & 0.91 & 65 & 114.48 & 23.10 & 362.00 & 1.69 & 60.90 & 0.000260 \\
\hline 56 & 532 & 2.61 & 65 & 148.58 & 28.60 & 571.30 & 2.73 & 45.40 & 0.000220 \\
\hline 57 & 612 & 2.78 & 65 & 127.72 & 24.62 & 229.50 & 1.14 & 83.38 & 0.000210 \\
\hline 58 & 558 & 3.04 & 72 & 112.43 & 23.30 & 345.00 & 1.97 & 65.70 & 0.000260 \\
\hline 59 & 554 & 2.49 & 72 & 194.11 & 27.00 & 761.00 & 2.74 & 50.00 & 0.000260 \\
\hline 60 & 572 & 2.73 & 72 & 131.33 & 26.00 & 320.20 & 1.56 & 65.00 & 0.000215 \\
\hline 61 & 839 & 4.62 & 220 & 114.40 & 1.10 & 610.00 & 7.12 & 229.40 & 0.000100 \\
\hline 62 & 916 & 5.36 & 80 & 45.68 & 2.23 & 483.12 & 16.92 & 224.77 & 0.000100 \\
\hline 63 & 1000 & 4.72 & 220 & 102.78 & 1.40 & 563.52 & 7.05 & 224.60 & 0.000100 \\
\hline 64 & 890 & 5.02 & 220 & 108.49 & 0.35 & 643.92 & 8.06 & 225.65 & 0.000100 \\
\hline 65 & 952 & 5.27 & 220 & 172.00 & 1.40 & 886.85 & 11.95 & 224.10 & 0.000100 \\
\hline 66 & 972 & 5.35 & 220 & 85.82 & 3.00 & 845.70 & 14.81 & 225.60 & 0.000100 \\
\hline 67 & 964 & 4.45 & 220 & 85.77 & 3.60 & 859.70 & 15.06 & 225.20 & 0.000100 \\
\hline 68 & 935 & 5.45 & 80 & 72.20 & 0.45 & 698.82 & 13.61 & 230.05 & 0.000100 \\
\hline 69 & 988 & 4.86 & 220 & 67.30 & 0.40 & 722.30 & 14.05 & 229.60 & 0.000100 \\
\hline 70 & 1000 & 5.31 & 220 & 76.52 & 0.51 & 665.20 & 12.94 & 227.48 & 0.000100 \\
\hline 71 & 839 & 4.62 & 220 & 77.07 & 0.10 & 1047.14 & 20.37 & 233.60 & 0.000100 \\
\hline 72 & 916 & 5.36 & 220 & 80.03 & 6.15 & 650.76 & 11.40 & 228.85 & 0.000100 \\
\hline 73 & 1000 & 4.72 & 220 & 63.00 & 6.70 & 993.36 & 19.33 & 227.30 & 0.000100 \\
\hline 74 & 890 & 5.02 & 220 & 89.17 & 7.00 & 1201.04 & 19.12 & 229.00 & 0.000100 \\
\hline 75 & 952 & 5.27 & 220 & 119.89 & 5.70 & 1332.96 & 12.97 & 231.10 & 0.000100 \\
\hline
\end{tabular}


Table 1 (continued)

\begin{tabular}{|c|c|c|c|c|c|c|c|c|c|}
\hline Well No. & $\begin{array}{c}\text { TDS } \\
(\mathrm{ppm})\end{array}$ & SAR & $\begin{array}{l}\text { Well safe } \\
\text { yield }(Q) \\
\left(\mathrm{m}^{3} / \mathrm{h}\right)\end{array}$ & $\begin{array}{l}\text { Tested useful } \\
\text { thickness } \\
\text { (Screened } \\
\text { portion) (m) }\end{array}$ & $\begin{array}{l}\text { Depth to } \\
\text { water } \\
\text { (mbgl) }\end{array}$ & $\begin{array}{l}\text { Transmissivity } \\
(\mathrm{T}) \text { from } \\
\text { pumping tests } \\
\left(\mathrm{m}^{2} / \text { day }\right)\end{array}$ & $\begin{array}{l}\text { Hydraulic } \\
\text { conductivity } \\
(\mathrm{K}) \text { from } \\
\text { pumping tests } \\
\text { (m /day) }\end{array}$ & $\begin{array}{l}\text { Piezometric } \\
\text { surface } \\
\text { (masl) }\end{array}$ & $\begin{array}{l}\text { Storage } \\
\text { coefficient } \\
\text { (S) }\end{array}$ \\
\hline 76 & 972 & 5.35 & 220 & 98.64 & 11.20 & 1163.20 & 18.52 & 225.80 & 0.000100 \\
\hline 77 & 964 & 4.45 & 220 & 114.29 & 10.95 & 1100.89 & 12.85 & 227.55 & 0.000100 \\
\hline 78 & 1740 & 5.20 & 220 & 102.91 & 9.05 & 935.57 & 12.60 & 228.45 & 0.000100 \\
\hline 79 & 1100 & 5.81 & 220 & 114.24 & 11.30 & 1247.14 & 13.65 & 227.50 & 0.000100 \\
\hline 80 & & 4.45 & 220 & 85.79 & 6.08 & 1188.90 & 18.93 & 229.92 & 0.000100 \\
\hline 81 & 1302 & 6.19 & 220 & 85.74 & 7.10 & 927.50 & 16.24 & 227.90 & 0.000100 \\
\hline 82 & & & 220 & 111.68 & 8.70 & 1179.57 & 13.77 & 223.30 & 0.000100 \\
\hline 83 & $\overline{7} 72$ & $\overline{4} .04$ & 60 & 45.88 & 3.55 & 571.70 & 20.02 & 222.45 & 0.000100 \\
\hline 84 & 736 & 4.21 & 140 & 42.17 & 0.80 & 725.40 & 25.40 & 225.20 & 0.000100 \\
\hline 85 & 1012 & 5.07 & 220 & 108.65 & 12.34 & 1296.35 & 17.46 & 222.66 & 0.000100 \\
\hline 86 & 772 & 4.04 & 220 & 108.63 & 7.80 & 1390.80 & 18.74 & 224.20 & 0.000100 \\
\hline 87 & & & 220 & 108.63 & 8.64 & 1424.50 & 17.82 & 225.36 & 0.000100 \\
\hline 88 & $\overline{1} 318$ & $\overline{7} .27$ & 220 & 102.78 & 8.55 & 1335.98 & 18.00 & 227.45 & 0.000100 \\
\hline 89 & 1304 & 6.83 & 220 & 102.92 & 7.65 & 1489.24 & 21.73 & 228.85 & 0.000100 \\
\hline 90 & 1184 & 6.19 & 220 & 104.98 & 10.18 & 1285.55 & 17.32 & 227.82 & 0.000100 \\
\hline
\end{tabular}

Abbreviations: $T D S$ total dissolved solids; $S A R$ sodium adsorption ratio; $m b g l$ meters below ground level; masl meters above sea level

which coincides with the general trend of groundwater movement of the Nubian Sandstone in the Western Desert (Heinl and Thorweihe 1993). Some local groundwater is moving from $\mathrm{W}$ to $\mathrm{E}$, especially at the northern part of the area. Also, the equipotentiometric levels are topographically controlled. This situation is in agreement with the work published by Fathy et al. (2002).

The depth to groundwater similarly varies and reflects the topographic and structural setting of the area. It varies from 18.43 (well 1) to $35.45 \mathrm{mbgl}$ (well 9) in the northern part of the area and from 2.3 (well 46) to $29 \mathrm{mbgl}$ (well 37 in the middle part of the area. In the southern part of the area, the depth to water ranges from 0.35 (well 64) to $11.2 \mathrm{mbgl}$ (well 76).

\section{Aquifer hydraulic conductivity (K)}

The aquifer is heterogeneous with a variation in lithology, structure and grain size, which led to a variation in $K$ values across the $290-\mathrm{km}$ length of the study area. Hydraulic conductivity, $K$, is generally approximated by dividing the transmissivity, $T$, by the aquifer thickness, $b$ (Eq. 1):

$(K=T / b)$
These wells are fully penetrating the aquifers. The fully penetrated thickness of the water bearing layers is used in the calculations, whereas some non-effective intervals or those having higher concentrations of ferruginous deposits are blocked or cased.

The structural graben areas favor a local hydrogeological closed system that is characterized by relative groundwater stagnation and low $K$ values (well $46 ; 0.48 \mathrm{~m} /$ day, well $35 ; 1.89 \mathrm{~m} /$ day and well $15 ; 1.85 \mathrm{~m} /$ day). The Quseir Formation encountered in the northern part is characterized by a higher percentage of low permeability sediments and could be considered as semi-pervious layers that hamper the groundwater movement across them. This fact could explain the low permeability values in this part of the study area (Fig. 4). The calculated hydraulic conductivity of Taref Sandstone varies from $0.05 \mathrm{~m} /$ day (well 40 ) in the middle part of the area to $25.4 \mathrm{~m} /$ day (well 84) in the southern part (Bir El-Shaab area). Generally, the hydraulic conductivity increases towards the south. This is attributed to the increase of grain size and sand percentage due south (Tables 1 and 2).

\section{Aquifer transmissivity (T)}

Many of the transmissivity and hydraulic conductivity values that were compiled were based on specific-capacity

Table 2 Peripheral and mean values used in determining hydrogeological priority areas for development

\begin{tabular}{|c|c|c|c|c|c|c|c|c|c|}
\hline & $\begin{array}{l}\text { TDS } \\
(\mathrm{ppm})\end{array}$ & SAR & $\begin{array}{l}\text { Well safe } \\
\text { yield }(Q) \\
\left(\mathrm{m}^{3} / \mathrm{h}\right)\end{array}$ & $\begin{array}{l}\text { Tested useful } \\
\text { thickness (m) }\end{array}$ & $\begin{array}{l}\text { Depth to } \\
\text { water before } \\
\text { pumping } \\
\text { (mbgl) }\end{array}$ & $\begin{array}{l}\text { Transmissivity } \\
\text { (T) }\left(\mathrm{m}^{2} / \text { day }\right)\end{array}$ & $\begin{array}{l}\text { Hydraulic } \\
\text { conductivity } \\
(K)(\mathrm{m} / \text { day })\end{array}$ & $\begin{array}{l}\text { Piezometric } \\
\text { surface (masl) }\end{array}$ & $\begin{array}{l}\text { Storage } \\
\text { coefficient }(S)\end{array}$ \\
\hline Min. & 450 & 0.916 & 60 & 42.17 & 0.1 & 10.65 & 0.052 & 45.4 & 0.000030 \\
\hline Max. & 1870 & 17.682 & 220 & 291.25 & 35.54 & 1489.24 & 25.4 & 233.6 & 0.000541 \\
\hline Mean & 1057 & 5 & 170 & 158 & 15 & 593 & 7 & 149 & 0.000140 \\
\hline
\end{tabular}




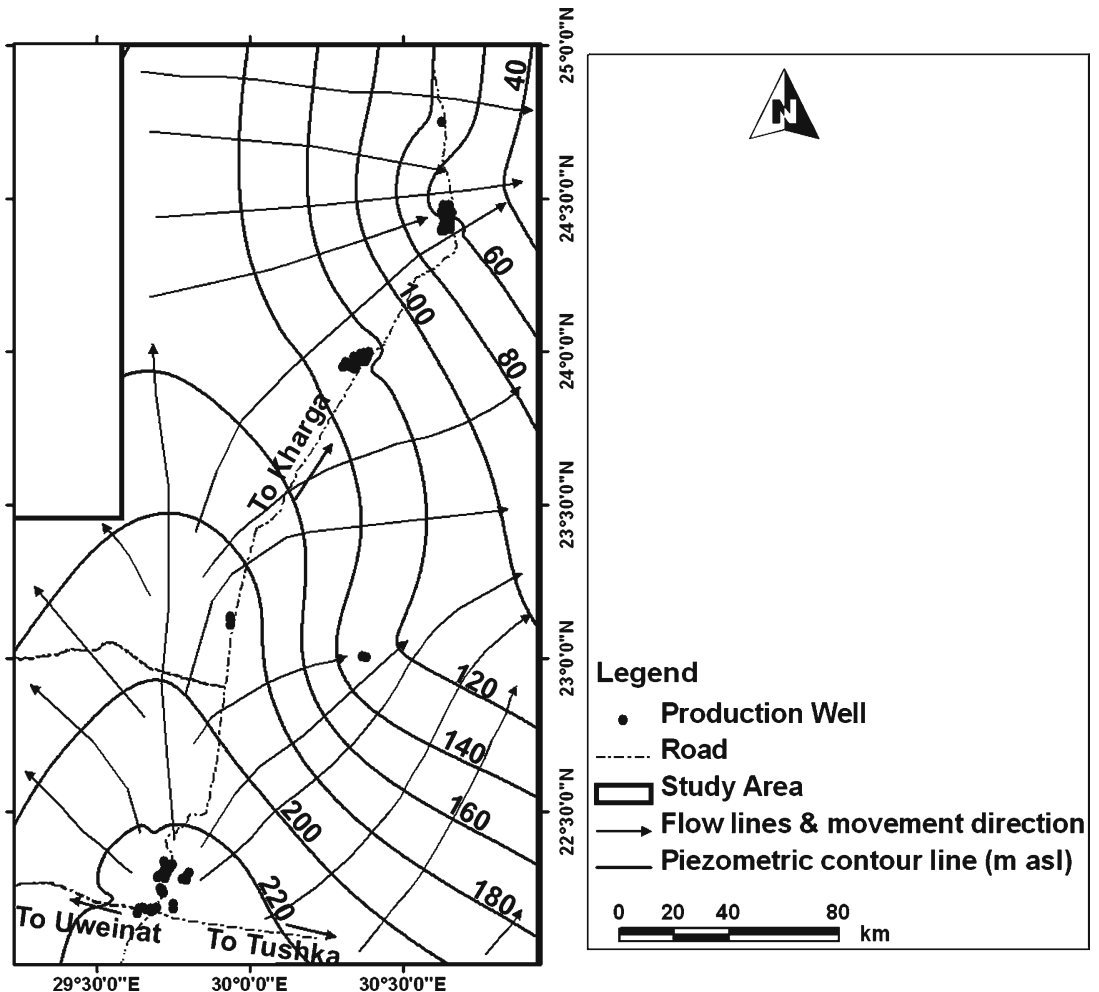

Fig. 7 Potentiometric surface and flow net for the Nubian Sandstone aquifer of the Darb el-Arbain area

and step-drawdown data. Although estimates of transmissivity and hydraulic conductivity derived from specific-capacity and step-drawdown data are generally not as accurate as estimates from time-drawdown data (Theis et al. 1963; Mace 1997). The following equation, based on the Cooper and Jacob (1946) approximation of the Theis equation (Driscoll et al. 1986) for flow to a well in a confined aquifer, computes the specific capacity, $Q / S$, of a well (Eq. 2):

$T=264 Q / s \log \left\{0.03 T t / r_{w}^{2} S\right\}$

Where $Q$ is constant discharge rate $\left(\mathrm{m}^{3} /\right.$ day), $r_{\mathrm{w}}$ is the pumped-well radius (m), $S$ is the storage coefficient (dimensionless), $T$ is transmissivity $\left(\mathrm{m}^{2} /\right.$ day) and $t$ is time (minutes).

The transmissivity of the Taref Sandstone aquifer in the Bir El-Shab area is calculated by analysis of the practical data from pumping tests, which were carried out by the General Authority for Rehabilitation Projects and Agricultural Development (GARPAD unpublished report, 1998/2000). The transmissivity for these wells varies from $10.65 \mathrm{~m}^{2} /$ day (well 40 ) in the middle part of the area to $1,489 \mathrm{~m}^{2}$ /day (well 89) in the southern part (Bir El-Shab area), which indicates that the increase in transmissivity is mainly in the southern direction (Tables 1 and 2). This is attributed to the increase of the grain size and sand percentage due south. However, it could be concluded that the aquifer in the southern area (Bir El Shab area) is considered as an aquifer with high potential.

\section{Storage coefficient (S)}

The aquifer-system storage coefficient, $S$, is defined as the sum of the skeletal storage coefficients of the aquitards (i.e. Kiseiba and /or Quseir formations) and aquifers (i.e. Taref Formation) plus the storage attributed to water compressibility (Kruseman et al. 1990) (Eq. 3).

$$
S=S_{\mathrm{sw}}^{\prime}\left(\Sigma b^{\prime}\right)+S_{\mathrm{sw}}(\Sigma b)=\beta_{\mathrm{f}} \rho g\left[n^{\prime}\left(\Sigma b^{\prime}\right)+n(\Sigma b)\right]
$$

Where $n^{\prime}$ and $n$ are the porosities, and $S^{\prime} s w$ and $S s w$ are the specific storages of water, of the aquitards and aquifers, respectively, $\beta_{\mathrm{f}}$, is the water (fluid) compressibility with units of pressure ${ }^{-1}, \rho$ is the water mass density and $g$ is the gravitational constant.

In other words, $S$ is used to represent the storage coefficient of an aquifer, which is the volume of water released from an aquifer per 1-m surface area per 1-m change in head. Notice that the relation is not associated with water flowing through an aquifer; rather it relates to an aquifer's ability to store water. Mathematically, the storage coefficient is dimensionless as the following equation illustrates (Eq. 4).

$S=Q /\left(A x\left(h-h^{\prime}\right)\right)$

Where $S$ is the storage coefficient, $Q$ is the volume of water in $\mathrm{m}^{3}, A$ is the surface area in $\mathrm{m}^{2}$ and $\left(h-h^{\prime}\right)$ is the head change in $\mathrm{m}$.

The storage coefficient $(S)$, which is a factor of storage capacity and aquifer ability to store water (Lohman 1972), reached its maximum value $\left(1 \times 10^{-4}\right)$ in the southern part 
(El-Shab area) representing the specific leaky confined aquifer characteristic value, whereas the minimum value $\left(3 \times 10^{-5}\right.$; well 1) is encountered in the northern part (Tables 1 and 2). However, these values assume that compressibility of aquifer skeleton (Taref Formation) and aquitard skeleton (Kiseiba or Quseir formations) are equivalent. It is obvious that the storage coefficient of this aquifer increases in the southern direction as a function of thickness increasing in the same direction. In conclusion, when applying the previously discussed hydrogeological parameters to the prepared GIS geospatial model, they reflected and reinforced the preliminary assessment for the priority areas for hydrogeological development.

\section{Total dissolved solids (TDS) and sodium adsorption ratio (SAR)}

The highest values of TDS are found in the southern and middle parts. The TDS values vary from $736-1,740 \mathrm{ppm}$ in the southern part to $916-1,870 \mathrm{ppm}$ in the middle part to $450-884 \mathrm{ppm}$ in the far northern part. The highest value of salinity is encountered at the southern-middle part (well $78,1,740 \mathrm{ppm}$; well $28,1,870 \mathrm{ppm}$ ). Similarly, the SAR varies with the same trend, where the highest value was encountered at the middle part (17.68).

\section{Hydrogeological priority areas for sustainable development}

In the present work, GISs, as efficient tools for digital database and geospatial modeling, were used to summarize and manipulate the hydrogeological and hydrological data characteristics of the aquifer system for determining the hydrogeological priority areas for sustainable present and future development (Fig. 8a-e). The geospatial modeling technique, which is a powerful module in ArcGIS software, was used to determine such areas depending on certain specific and determined hydrogeological parameters. The hydrogeological studies of the Nubian Sandstone Aquifer System were undertaken according to the previously collected bore well data and the recently inventoried field data obtained from selected wells in the Darb el-Arbain area (2007 and 2008; NARSS 2008, where the regional flow conditions and structural setting of the Nubian Sandstone Aquifer System in southern Western Desert of Egypt were studied using remote sensing, GIS and mathematical modeling techniques, in an internal unpublished project funded by NARSS).

The unbiased spatial analysis was performed on composite GIS layers to determine the most important priority units for development and future artificial recharge planning. These priority units were determined according to definite criteria with field truthing (NARSS unpublished report, see previous details), such as: groundwater salinity $(\mathrm{ppm})$, depth to groundwater (mbgs), aquifer hydraulic conductivity (m/day), well safe yield $\left(\mathrm{m}^{3} /\right.$ day) and sodium adsorption ratio (SAR).
Thus, the priority areas could be described as integrated roles of these criteria. For a variety of reasons, these priority areas may be determined to be of highest priority for protection and suitable places for future augmentation if there are available recharge sources. A groundwater protection plan can be used to maintain such areas. For immediate development of the groundwater resource, priority area $I$ is determined to satisfy the following criteria:

1. Water quality for agricultural use is satisfactory low (TDS $\leq 1057$ ppm)

2. Economically optimum groundwater depth $(\leq 15 \mathrm{mbgl})$

3. Sodium adsorption ratio is within the safe limit for agriculture $(\mathrm{SAR} \leq 5)$

4. Hydraulic conductivity is high enough ( $K \geq 7 \mathrm{~m} /$ day)

5. Adequate well safe yield for water consumption $(Q \leq$ $170 \mathrm{~m}^{3} / \mathrm{h}$ )

The areas that meet all these requirements occupy mostly the central, western and southwestern parts, with some localized zones in the northern parts of the study area. However, the prioritization according to the groundwater salinity $(\leq 1,057 \mathrm{ppm})$ and SAR $(\leq 5)$ also designated the northern part of the study area as priority area I. Accordingly, priority area I represents an area that favors conditions that satisfy immediate and future sustainable development and needs a certain management and protection policies.

\section{Artificial recharging for groundwater augmentation}

Three major freshwater lakes (Tushka Lakes 1, 2 and 3) were detected and delineated from the Landsat ETM+ satellite image (taken in 2000). Tushka Lakes were formed after the completion of the Tushka drain, to dispose of the excess flood water of the River Nile (Figs. 5, 9 and 10). In 1996, when the lakes were initiated, only small water bodies (not real lakes) were formed because of seepage to groundwater.

The first true lake was initiated in 1998. In 2000, when water had filled this basin, three more lakes were formed. One of them is very small; the other three are about the same size. These lakes are considered as suitable sites for water harvesting and are sources for groundwater artificial recharge. The proportion, and thus volume, of direct lakewater infiltration strongly depends on lakebed clogging. Clogging is the formation of a layer on top of or within the lakebed which has a low hydraulic conductivity and therefore reduces the vertical flow rate of the water through it. The clogging material is the result of the infiltration and accumulation of both organic and inorganic suspended solids, precipitation of carbonates, ironand manganese-(hydr) oxides, and biological processes (Dillon et al. 2005). Up till now, the lakes ecosystem is still devoid of any sources of pollution that may threaten this new ecosystem. 

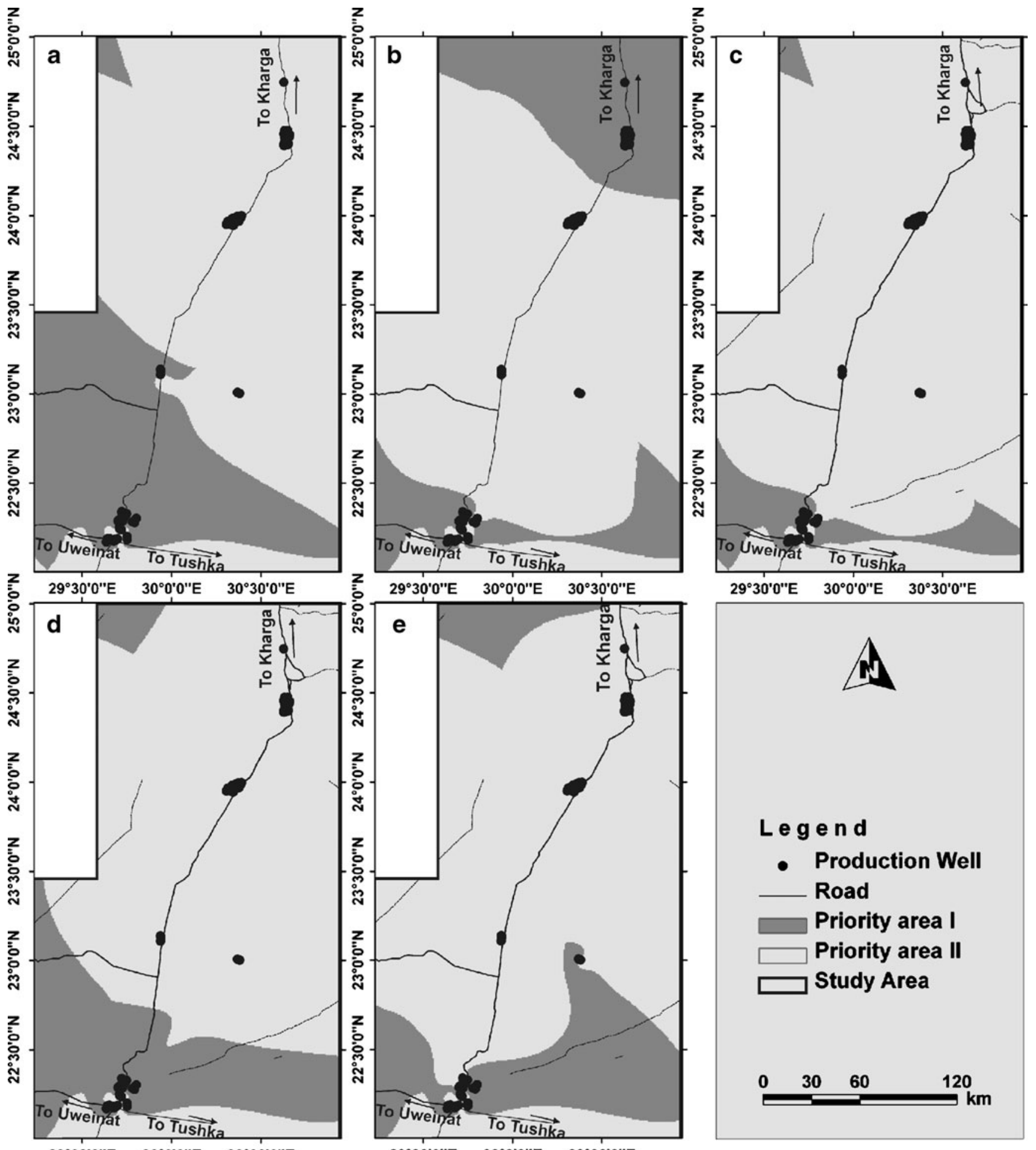

$29^{\circ} 30^{\prime} 0^{\prime \prime} \mathrm{E} \quad 30^{\circ} 0^{\prime} 0^{\prime \prime} \mathrm{E} \quad 30^{\circ} 30^{\prime} 0^{\prime \prime} \mathrm{E}$

$29^{\circ} 30^{\prime} 0^{\prime \prime}$ E $\quad 30^{\circ} 0^{\prime} 0^{\prime \prime} \mathrm{E} \quad 30^{\circ} 30^{\prime} 0^{\prime \prime} \mathrm{E}$

Fig. 8 a-e Determining priority areas for development using GIS techniques, according to the values of: a depth to water $\leq 15 \mathrm{mbgl}$ and groundwater salinity $\leq 1,057 \mathrm{ppm}$; $\mathbf{b}$ SAR $\leq 5$ with groundwater salinity $\leq 1057 \mathrm{ppm}$; c depth to water $\leq 15$ mbgl and groundwater salinity $\leq 1,057 \mathrm{ppm}$ and $\mathrm{SAR} \leq 5$; d hydraulic conductivity $(\mathrm{K}) \geq 7 \mathrm{~m} /$ day with groundwater salinity $\leq 1057 \mathrm{ppm}$; e TDS $\leq 1,057 \mathrm{ppm}$ and well safe yield (Q) $\geq 170 \mathrm{~m}^{3} / \mathrm{h}$

From the hydrogeological and economic points of view, it is feasible to conduct an ASR for the following reasons:

- Hydraulic conductivity and storage coefficient are high enough to store a large quantity of lake water for a long time. In the southern region (Bir El-Shab area) the $K$ range is $7.05-25.40 \mathrm{~m} /$ day and average $S$ is $1 \times 10^{-4}$, whereas in the middle area, the $K$ range is $1.03-2.98 \mathrm{~m} /$ day and $S$ range is $0.89 \times 10^{-4}-2.65 \times 10^{-4}$, and in the northern area, the $K$ range is $1.14-2.76 \mathrm{~m} /$ day and $S$ range 


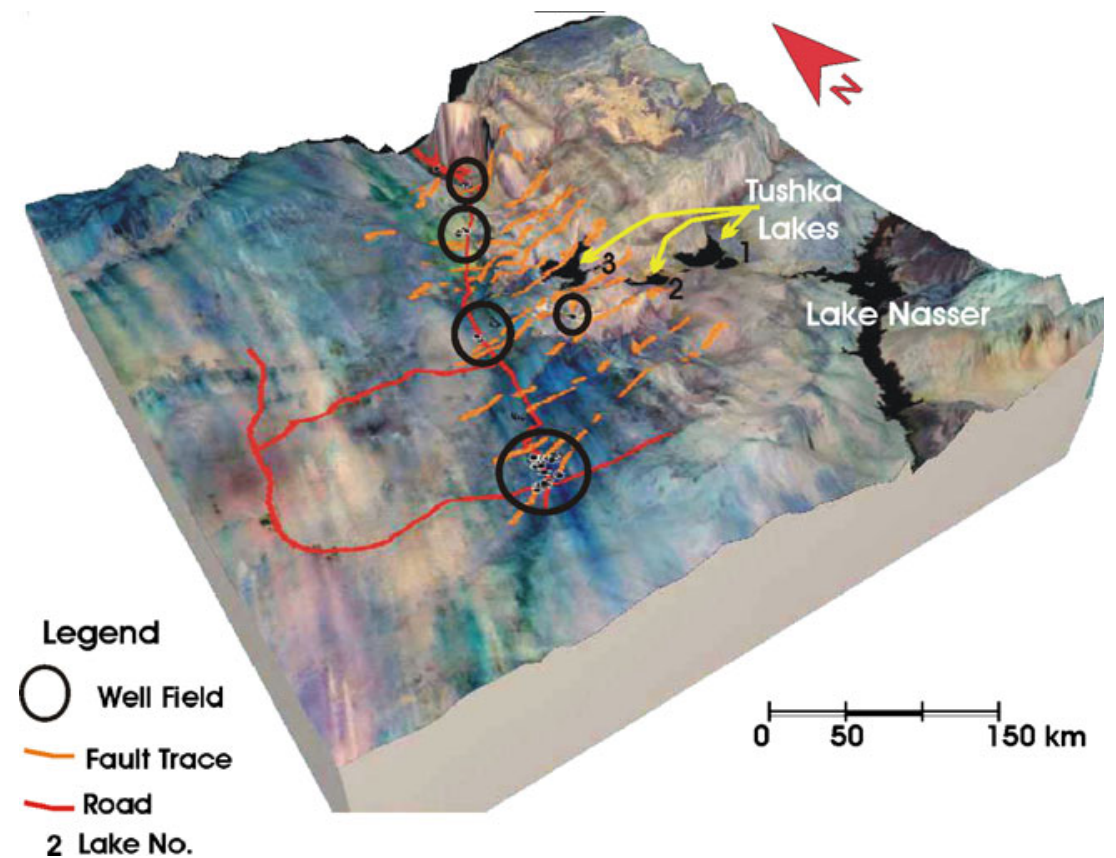

Fig. 9 Landsat ETM+ satellite image block diagram (vertical exaggeration is $\times 15$ ) with data layers of topography, groundwater wells and the hydrogeological faulting system

is $3 \times 10^{-5}-54 \times 10^{-4}$. Accordingly, the southern area (Bir El-Shab) is highly favorable (followed by the middle area) for conducting an ASR Program.

- The aquifer is (semi) confined so that the water injected remains contained in a limited space well below land surface.
- The groundwater to be recharged has a higher salinity than that of the recharge water (Dillon et al 1997), i.e. Tushka Lakes. The TDS concentrations of groundwater in the Bir El-Shab area are within the range of 736$1,740 \mathrm{ppm}$, the middle area is $916-1,870 \mathrm{ppm}$ and the northern area is $450-884 \mathrm{ppm}$. Thus, these parameters

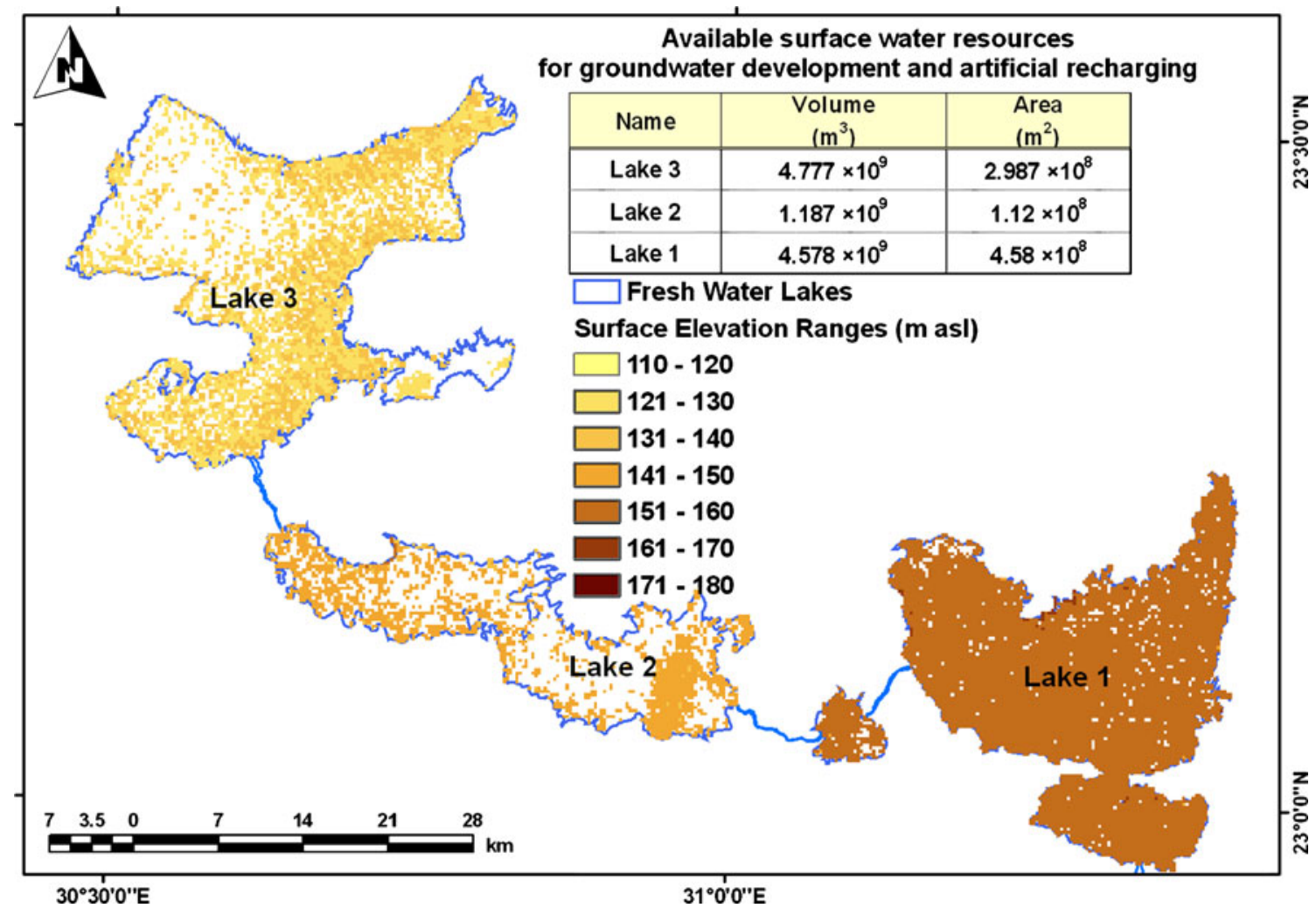

Fig. 10 Calculated areas and volumes of water of Tushka Lakes from DEM and GIS (According to Landsat ETM+ satellite image taken in 2000) 
also suggest the southern and middle areas as suitable sites for conducting an ASR program.

- The tendency of clay minerals in the aquifer to mobilize by deflocculation is low. Clay minerals could provoke mechanical clogging of the aquifer when the particles become stranded in the pore necks. This tendency is low when the sodium adsorption ratio (SAR) of the injectate (Tushka Lakes) and of the native groundwater is low, the groundwater TDS concentration is high, and the clay mineral content is very low, as characterized in this case study. The salinity of Tushka Lakes is about 194 ppm and the SAR is 1.29 (Elewa 2006), which are excellent values for a suitable injectate.

- A large surface water storage facility is sufficient for supplying sustainable feed water for a long time. According to the given areas and water volumes of these lakes (which are augmented yearly by the excessive Nile flooding), the surface water storage is sufficient for a long term ASR program.

The Tushka Lakes are characterized by a general slope towards the Tushka Depression, occurring to the west of Lake Nasser (Figs. 9 and 10). The lakes exhibit varying elevations from 150-160 masl at lake 1 , to $140-150$ at lake 2, and 130-140 masl at lake 3 (Fig. 10). The average depth of these lakes is about $10 \mathrm{~m}$ with more variation between banks and centers in Lake 3. The calculations of areas, elevations and the corresponding volumes of reserved water in the three Tushka lakes (the lakes are interconnected with each other via spill ways) were performed using a digital elevation model (DEM) and GIS techniques. The areas of these lakes range from $112.66 \mathrm{~km}^{2}$ (lake 2) to $458.83 \mathrm{~km}^{2}$ (lake 1). The corresponding reserved water ranges from $1,187.25 \mathrm{~km}^{3}$ (lake 2) to $4,777.69 \mathrm{~km}^{3}$ (lake 3). At some parts of the lakes there are numerous faults and fractures, which form natural conduits for vertical water percolation. These important hydrogeological faults and fractures are dominant on the geological map and clearly seen on the Landsat ETM+ satellite images (Figs. 3 and 5). The E-W main faults exhibit ideal trends for direct conveyance of surface lake water to augment the Nubian Sandstone Aquifer System of Darb el-Arbain area, with other intensified fractures of different trends, which are widely spread all over the study area. Accordingly, natural recharge for the Nubian Sandstone Aquifer System in the area, by the downward percolation from the Tushka Lakes, is expected and needs more investigation to be fully confirmed and evaluated.

The previously determined priority areas for hydrogeological development by GIS techniques and the other hydrogeological parameters suggest the southern and middle parts are ideal places, having the most favorable conditions for carrying out an ASR program. For artificial conveyance of lake water by pipelines, $50-60 \mathrm{~km}$ of pipeline will be needed from lake 3 to the nearest well field (wells 29-30; wells 11-46) in the middle part of the area, and about $125 \mathrm{~km}$ of pipeline from lake 2 to reach the well field of the southern part (El-Shab area; wells 6190; Figs. 5 and 9). Distance and feasible cost suggest the middle part of the area for implementing an ASR program, whereas the GIS model, by determining priority areas for development, designates the southern part. The groundwater movement direction and hydrogeological characteristics favor the southern area as a starting point for water injection and aquifer development. However, this preliminary planning for an ASR program needs further investigation concerning the design of any artificial recharging program and the recharging wells. A detailed water mass balance mathematical model is needed to assert the exact future hydro-environmental consequences of this policy on the Nubian aquifer. A full monitoring system for recording the changes in water levels, flow and quality needs to be implemented before an ASR program is implemented.

This will be a true pioneering program and the most appropriate ASR program for Egypt. The ongoing reclamation projects are scheduled for future expansion with a consequent increase in groundwater demands. Hence, these lakes should be used sooner or later in augmenting the depleting groundwater resource, to cope with these demands. It is better to use them than leave them and risk environmental deterioration.

\section{Summary and conclusions}

The Nubian Sandstone Aquifer is one of the most important groundwater systems of the Western Desert. The present work highlighted the efficient contribution of GIS database and geospatial modeling for evaluating and determining hydrogeological priority areas for sustainable development. The decisive hydrogeological parameters used in the constructed geospatial model are: depth to groundwater (mbgl), groundwater salinity ( $\mathrm{ppm})$, hydraulic conductivity ( $\mathrm{m} /$ day) and sodium adsorption ratio (SAR). The spatial model highlighted areas that meet optimum values of these parameters i.e. mostly the central, western and southwestern parts with some localized zones in the northern parts of Darb el-Arbain area. Accordingly, priority area I represents areas that favor conditions that satisfy immediate and sustainable development, and needs certain management and protection policies to maintain their favorable status. The newly formed freshwater Tushka Lakes lying to the near east of the study area represent a new evolved source of water suitable for augmentation and development of the Nubian Sandstone Aquifer System. The GIS technique suggests that an ASR program should be performed in the southern part, or even in the middle part of the area. More investigations and mathematical modeling techniques are needed for predicting the exact hydro-environmental consequences of implementing such a program.

Acknowledgements The authors wish to express their deep gratitude to the National Authority for Remote Sensing and Space Sciences for funding the project from which the data for this work was obtained. Thanks also go to the anonymous reviewers for their suggestions and comments regarding the manuscript. Special 
appreciation goes to Dr. Shemin Ge (Managing Editor) and Sue Duncan (Technical Editorial Advisor) of Hydrogeology Journal for their valuable comments and advice.

\section{References}

Burrough PA, Frank AU (1995) Concepts and paradigms in spatial information systems: are current geographical information systems truly generic? Int J Geogr Inf Sys 9(2):101-116

CONOCO (Continental Oil Company) (1987) Geological map of Egypt (scale 1: 500,000). Conoco Inc. in collaboration with Freie Universitat Berlin

CONOCO (Continental Oil Company) (1989) Geological map of Egypt (scale 1: 500,000). Conoco Inc. in collaboration with Freie Universitat Berlin

Cooper HH Jr, Jacob CE (1946) A generalized graphical method for evaluating formation constants and summarizing well field history. Trans Am Geophys Union 27:526-534

Dillon P, Pavelic P, Sibenaler X, Gerges N, Clark R (1997) Storing storm water runoff in aquifers. Aust Water Wastewater Assoc J Water 24(4):7-11

Dillon P, Toze S, Pavelic P, Skjemstad J, Davis G, Miller R, Correll R, Kookana R, Ying GG, Herczeg A, Fildebrandt S, Banning N, Gordon C, Wall K, Nicholson B, Vanderzalm J, Le Gal La Salle C, Gibert M, Ingrand V, Guinamant J-L, Stuyfzand P, Prommer H, Greskowiak J, Swift R, Hayes M, O'Hara G, Mee B, Johnson I (2005) Water quality improvements during aquifer storage and recovery, vol 1: water quality improvement processes. Final report, AWWARF project 2618, AWWARF, Denver, CO

Driscoll FG et al (1986) Groundwater and wells. Johnson, St. Paul, $\mathrm{MN}, 1089 \mathrm{pp}$

Elewa HH (2006) Water resources and geomorphological characteristics of Tushka and West of Lake Nasser, Egypt. Hydrogeol J 14:942-954

ESRI (2007) ArcGIS 9.x Software and user manual. Environmental Systems Research Institute, Redlands, CA. http://www.esri.com. Cited January 2009

Fathy RG (2003) Contributions the subsurface geologic structural pattern of South El-Shab area, South Western Desert, Egypt. J Appl Geophys Soc Egypt 2:53-61

Fathy RG (2004) Contributions to the subsurface geologic structural pattern of the northern and the middle parts of Darb El-Arbeain area, South Western Desert, Egypt. J Appl Geophys Soc Egypt $3: 61-75$
Fathy RG, EL-Hefnawy M, Abd EL-Hamid A (2001) Contributions to the hydrogeological aspects of the groundwater aquifers in southern part of Darb EL-Arbeain area, southern portion of Western Desert, Egypt. Al-Azhar Bull Sci 12(2):175-194

Fathy RG, EL NM, Atef AA, El-Gammal NM (2002) Contributions to the hydrogeological and hydrochemical characteristics of Nubia Sandstone aquifer in Darb Al-Arbeain, South Western Desert, Egypt. Al-Azhar Bull Sci 13(2):69-100

Ghoubashi SY (2004) Comparative hydrological studies of the Nubia Sandstone aquifer system in East El-Oweinat and Bir El Shab areas, South Western Desert, Egypt. PhD Thesis, Al-Azhar Univ., Egypt, 187 pp

Heinl M, Thorweihe U (1993) Groundwater resources and management in SW-Egypt. In: Meissner B, Wycisk P (eds) Geopotential and ecology-analysis of a desert region. Catena Supplement 26, Catena, Cremlingen, Germany, 199 pp

Issawi B (1978) New findings on the geology of Uweinat, Gilf Kebir, Western Desert, Egypt. Ann GSE, Cairo 4:275-293

Klitzsch E, Squyres CH (1990) Paleozoic and Mesozoic geological history of northeastern Africa based upon new interpretation of Nubia strata. Am Assoc Petrol Geol Bull 74:1203-1211

Korany EA, Fathy RG, Nagaty MEl (2002) Contributions to the hydrogeology of Nubia Sandstone aquifer in the middle part of Darb El-Arbeain, south Western Desert, Egypt. J Sedimentol Soc Egypt 10:119-143

Kruseman GP, de Ridder NA et al (1990) Analysis and evaluation of pumping test data. The Netherlands International Institute for Land Reclamation and Improvement, Wageningen, The Netherlands, $377 \mathrm{pp}$

Lohman SW (1972) Groundwater hydraulics. US Geol Surv Prof Pap 708, $70 \mathrm{pp}, 9$ plates

Mace RE (1997) Determination of transmissivity from specific capacity data in a karst aquifer. Ground Water 35(5):738-742

Malczewski J (1999) GIS and multicriteria decision analysis. Wiley, New York

Said R (1962) The geology of Egypt. Elsevier, Amsterdam, 377 pp

Said R (1990) The geology of Egypt. Balkema, Rotterdam, The Netherlands, $734 \mathrm{pp}$

Theis CV (1935) The relation between the lowering of piezometric surface and the rate and duration of discharge of a well using groundwater storage. Trans Am Geophys Union 16:519-524

Theis CV, Brown RH, Myers RR (1963) Estimating the transmissibility of aquifers from the specific capacity of wells: methods of determining permeability, transmissivity, and drawdown. US Geol Surv Water Suppl Pap 1536-I 